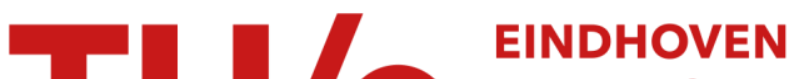 \\ UNIVERSITY OF \\ TECHNOLOGY
}

\section{Ethical issues in human embryonic stem cell research}

Citation for published version (APA):

Nickel, P. J. (2008). Ethical issues in human embryonic stem cell research. In K. R. Monroe, R. B. Miller, \& J. S. Tobis (Eds.), Fundamentals of the stem cell debate : the scientific, religious, ethical and political issues (pp. 6278). University of California Press.

Document status and date:

Published: 01/01/2008

\section{Document Version:}

Publisher's PDF, also known as Version of Record (includes final page, issue and volume numbers)

\section{Please check the document version of this publication:}

- A submitted manuscript is the version of the article upon submission and before peer-review. There can be important differences between the submitted version and the official published version of record. People interested in the research are advised to contact the author for the final version of the publication, or visit the $\mathrm{DOI}$ to the publisher's website.

- The final author version and the galley proof are versions of the publication after peer review.

- The final published version features the final layout of the paper including the volume, issue and page numbers.

Link to publication

\section{General rights}

Copyright and moral rights for the publications made accessible in the public portal are retained by the authors and/or other copyright owners and it is a condition of accessing publications that users recognise and abide by the legal requirements associated with these rights.

- Users may download and print one copy of any publication from the public portal for the purpose of private study or research.

- You may not further distribute the material or use it for any profit-making activity or commercial gain

- You may freely distribute the URL identifying the publication in the public portal.

If the publication is distributed under the terms of Article 25fa of the Dutch Copyright Act, indicated by the "Taverne" license above, please follow below link for the End User Agreement:

www.tue.nl/taverne

Take down policy

If you believe that this document breaches copyright please contact us at:

openaccess@tue.nl

providing details and we will investigate your claim. 
The publisher gratefully acknowledges the generous contribution to this book provided by the Barbara S. Isgur Public Affairs Endowment Fund of the University of

California Press Foundation.

\section{Fundamentals of the Stem Cell Debate}

The Scientific, Religious, Ethical, and Political Issues

\section{Edited by}

Kristen Renwick Monroe, Ronald B. Miller, and Jerome S. Tobis 
University of California Press, one of the most distinguished university presses in the United States, enriche lives around the world by advancing scholarship in the humanities, social sciences, and natural sciences. Its activities are supported by the UC. Press Foundarion and by philanthropic contributions from individuals and institutions. For more information, visit

www.ucpress.cdu.

University of California Press

Berkeley and Los Angeles, California

University of California Press, Ltd.

London, England

(1) 2008 by The Regents of the University of California

Library of Congress Cataloging-in-Publication Data

Monroe, K. R.

Fundamentals of the Stem Cell Debate: The Scientific, Religious, Ethical, and Political Issues / Monroe.

Includes bibliographical references and index.

ISBN: 978-0-520-25210-3 (cloth : alk. paper)

ISBN: 978-0-520-25212-7 (pbk. : alk. paper)

I. Embryonic stem cells-Research-Moral and ethical aspects-United States. 2. Embryonic stem cellsResearch-Religious aspects-United States.

. Embryonic stem cells-Research-Political aspectsUnited States. I. Monroe, Kristen R., I946-

II. Miller, Ronald Baker. III. Tobis, Jerome S., I9 I $5-$ IDNL M: 1. Embryonic Stem Collo-Unied Stas 2. Biomedical Research - ethics-United States.

3. Human Experimentation-ethics-United States.

4. Public Policy-United States. QU 328 F98 I 2008

$\mathrm{QH}_{5} 88 . \mathrm{S}_{3}{ }_{3} \mathrm{~F} 862008$

$174.218-\mathrm{dc} 22$

2007031375

Manufactured in the United States of America

$\begin{array}{llllllll}15 & \mathrm{I}_{4} & \mathrm{I}_{3} & \text { I2 } & \text { II } & \text { IO } & 09 & 08\end{array}$

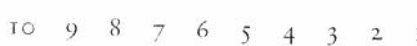

This book is printed on Cascades Enviro 100, a 100\% postconsumer waste, recycled, de-inked fiber. FSC recycled certified and processed chlorine free. It is acid free, Fcologo certified, and manufactured by BioGas energy.
To Paul H. Silverman, who pioneered work in genome and stem cell research and whose vision provided the drive behind this volume. Paul passed away July I $_{5}, 2004$. We shall miss him. 


\section{Ethical Issues in Human Embryonic Stem Cell Research}

\author{
Philip J. Nickel
}

As a moral philosopher, the perspective I will take in this chapter is one of argumentation and informed judgment about two main questions: whether individuals should ever choose to conduct human embryonic stem cell research and whether the law should permit this type of research. I will also touch upon a secondary question, that of whether the government ought to pay for this type of research. I will discuss some of the main arguments at stake and explain how the ethical conflict over these questions differs from the political conflict over them. I will be guided throughout by the assumption that the unique scientific and clinical promise of human embryonic stem cell research is significant. Those who have doubts about this assumption should consult other chapters in this volume in which the issue is addressed directly.

I begin with one of the basic facts relevant to the ethical issue of stem cell research: you and I, along with everybody else we know, developed out of clumps of primordial cells, which happen to be the very same clumps that serve as the source for human embryonic stem cells in the laboratory. Let us call these "source cells" for short, since they can be used in this way. Each individual has developed into whatever she is now out of a one-celled animal, which then became a blastocyst, a multicelled human embryo. These blastocysts are partly made up of an inner mass of cells, and the body of every adult person has developed out of this inner mass. It is this very same clump from the inner part of the blastocyst that consists of source cells for human embryonic stem cell research.
These cells can be extracted and grown into a laboratory specimen of extraordinary interest to scientists.

Before discussing the significance of the fact that all humans originate from these source cells, it is useful to begin by asking some perhaps rather simple-minded questions about how any one of us knows this fact to be true in the first place. How do I know that I developed from a single cell, and then a blastocyst? In my own case, the main way I know this is that other people hav told me so. I am a human-or so it is said-and scientists tell me that this is how humans develop. And I have every reason to think that scientists are telling the truth. It fits with what I know about procreative sex that between the point at which sperm meets egg and the time when the pregnant mother is carrying a fetus, there is an embryo inside her. This embryo, at one stage, becomes a blastocyst containing source cells. I take it that I was also conceived by my parents in this way and born in this way, and therefore that I too developed from a clump of source celis. Th se are the basic considerations that support my beliefs about the spatiotemporal contiguity of one particular clump of source cells with my present self. These beliefs come from knowledge acquired by a whole range of scientists over a considerable period of time, and this knowledge has gradually trickled down to me.

I do not remember being a single cell or a (part of a) blastocyst, so my belief that I developed out of a one-celled animal or a blastocyst is not based on experiential memory. One-celled organisms do not have the ability to store memories, so I am not able to recall any such memories. I do not remember when I first started remembering things; in fact, the occasion of my first memory is no doubt long forgotten. It happened before the first memories that I still remember now were impressed upon my mind. But I believe I can say with total certainty that I do not now remember, and I have never remembered, anything from the day when I was a one-celled animal, or for that matter from my blastocyst period.

Since I do not remember being a clump of source cells, it is hard for me to think of that clump of source cells as me. It is difficult to identify with the clump. The mere fact that the clump and I are spatiotemporally contiguous with each other is not enough to imply that it was $m e$; it is not enough to imply, in other words, that $I$ already existed so many years ago, in the form of a clump. The blastocyst, after all, did not have my mind and my awareness, or the ability to remember anything; in fact, about all it had of mine were some biological (e.g., genetic) similarities and my immediate family. Of course, it can also be said that when I am asleep and not dreaming I have no awareness of my surroundings and 
I do not have experiences that can be remembered. But my mind, my memories, and my ability to remember do not go out of existence when I am asleep; they simply go into remission. The blastocyst does not have a mind in remission, with a personal history; it does not have a mind at all. From this point of view, it is highly problematic to say that you and I were once blastocysts, as if the awareness and personal history, and ability to remember, with which we now identify, already existed at that earlier time. We should instead say, less problematically, that we deve' oped out of blastocysts.

With these thoughts in mind, we can go on to consider one of the important starting points for thinking about the ethics of human embryonic stem cell research. For many people, the central problem with stem cell research is that, had the source cells out of which you and I developed been used for stem cell research and then destroyed, then you and I would never have existed. We would never have had our lives, and we would not be doing whatever we are doing today. This fact is disturbing, since there is much that we would have lost by never existing, such as our entire lives, our children (if we have any), and so on. This, I think, is one of the basic facts that make people wary of the ethical permissibility of human embryonic stem cell research. It would seem that there are future people whose lives would never occur, were we to use human embryonic stem cells for research today. And by never having their lives occur, there is much those future people will lose. Let us call this the Loss of Future Life Problem for human embryonic stem cell research. ${ }^{1}$

It is important to distinguish this argument from the argument that when people use contraception, or even when they simply decide not to have procreative sex, they often thereby cause the loss of future human life by failing to cause all the possible people they could bring into existence to become actual persons with lives. The argument I am considering here does not assert that any action or omission that does not maximize the total amount of future life is therefore bad. Instead, the argument is that when there is a particular entity already on its way toward becoming a person, then depriving that entity of its future life, or making it lose the future life it otherwise would have had, is bad.

This way of framing the argument does not presuppose that I actually existed already - that I was already a person, namely, myself-during the blastocyst phase of my development. All that is required for the Loss of Future Life Problem is that the blastocyst is an entity with a likely future as a person, not that it is a person already. This is good because, as we were discussing above, the claim that a blastocyst is a person is difficult to defend: it runs into the difficulty that the blastocyst has no conscious mind, no awareness, and no personal history or ability to remember, whereas persons, of whom I am one, have minds and are identified strongly with those minds and with the associated abilities to think, remember, and have experiences.

Despite the intuitive force of the Loss of Future Life Problem, proponents of research using human embryonic stem cells can make a strong counterargument to it. To begin with, they can point out the overall consequences of doing such research: even if there is some possible future life that is lost when embryos are not implanted but are instead used for biomedical research, there is also a great deal of future life that can be gained because of that research-or so it is reasonable to predict. Moreover, the future life that can be gained can be gained not by merely possible people but by actual people who will already exist by the time the benefit comes to them. The potential benefits of such research to actual persons, down the road, are such as to cancel out the loss of life to merely possible persons. ${ }^{2}$

Most people, of course, do not regard the consequences of a particular action, in terms of pure benefit and harm, to be decisive in settling the question of whether that action is morally permissible. For example, if we could kill some actual persons in order to harvest their healthy organs, so that a greater number of other persons could live longer by having these various organs transplanted into them, the fact that there would be an overall benefit in terms of the number of years lived would hardly count in favor of the killing from a moral point of view. ${ }^{3}$ These ends do not justify these means. So, if the Loss of Future Life Problem is a decisive moral problem for human embryonic stem cell research, then the fact that a large number of people can be saved by such research is not a persuasive refutation of that problem.

However, the particular blastocysts that are, or would be, used by researchers are not on their way to having future lives. This is because of how they are acquired. One source of blastocysts is the pool of embryos frozen during in vitro fertilization (IVF) procedures and never implanted. In this case the particular stem cells in question do not come from a creature that is currently on its way toward developing into an adult human being. Therefore, there is no loss of future life involved in the decision to use stem cells from these embryos for research. Any decision that did lead to the loss of future life has already occurred at some earlier time, through the decision of the person or persons contracting for IVF services not to implant one or more of the embryos created by 
the clinic. Thus the Loss of Future Life Problem does not apply to the particular human embryonic stem cells that come from this source.

Of course, the Loss of Future Life Problem can be raised as a problem for IVF practices themselves. Although the ethical question of assisted fertility is a complicated issue in its own right, it is worth discussing for a moment because of its intimate relation to the issue of embryonic stem cell research. It might be thought that when embryos are created for possible use in fertility procedures but not implanted they are being deprived of future life. In fact, however, this is not so clear. By itself, neither ai egg nor a sperm can be deprived of future life because neither has the potential to develop into a whole person by itself. Hence, removing egg and sperm from persons for laboratory use does not in itself deprive any person of future life. Only removing a fertilized embryo from a woman and not reimplanting it results in the loss of future life. However, when fertilization occurs in vitro, outside the body, the fertilized egg is not being deprived of future life if it is not implanted. A fertilized embryo in vitro is not on its way toward a future life; left by itself it will inevitably die. It is only after it is implanted that that it begins on a developmental path toward personhood. Hence, not implanting an embryo fertilized in vitro does not cause it to lose future life that it otherwise would have had; rather, it simply omits to confer future life that the embryo otherwise would not have had. ${ }^{4}$ This is quite a different thing: failing to create future life is not morally problematic in itself.

In any case, the fact is that IVF practices are currently legally permitted, and there are many spare embryos already in existence that will never be implanted. Certainly they will not lose future life by being used for research. Thus, even if we concluded that IVF practices should be stopped, we would still need to address the separate question of what to do with the extra frozen embryos that already exist. If the alternative is simply to leave them in frozen storage, then it matters quite a bit that we could instead use these embryos for the ultimate goal of saving lives.

Embryonic stem cells for research can also come from donated egg cells and from embryos that are created expressly for the purpose of generating new stem cell lines. ${ }^{5}$ Egg cells can be fertilized in the lab, or, if we are to believe the results of an infamously fraudulent Korean study, they can be turned into quasi-embryos without fertilization, through the process of somatic cell nuclear transfer. ${ }^{6}$ In terms of the Loss of Future Life Problem, the key question is again whether the embryo is being deprived of future life, and again the answer depends on whether the embryo is removed from a woman's reproductive system, in which case it is likely that it is being deprived of future life that it would otherwise go on to have. If fertilization takes place outside a woman's body, by contrast, then the embryo is not already on its way toward a future life, so destroying it does not deprive it of that particular future. The same goes for a quasi-embryo created outside the body. ${ }^{7}$

So far, we have been leaving aside the most important part of the counterargument to the Loss of Future Life Problem. The important point is that, had the em cells that eventually developed into me been used for medical research instead, then I would have no complaint against that happening, because, after all, I would never have existed. Only existing people can be harmed through the deprivation of future life. Merely possible people cannot be harmed in this way; indeed, they cannot actually be harmed at all. This is because merely possible people do not exist. It is misleading to chalk up what I would have lost by not having developed and been born, as if the whole sequence of my subsequent life already existed, and were of value to me, before I existed. Although it matters to me now whether my future happens, this does not imply that it mattered, or should have mattered, to the blastocyst that became me, or that it should have mattered to somebody else on its behalf. This is because, at that time, what is now my future did not belong to any existing person. It only came to belong to me later, when I became a person.

I should say right away that I think this counterargument-especially the last part of it, which is conclusive in itself-is successful and that the Loss of Future Life Problem does not show that human embryonic stem cell research is morally impermissible. However, there are a couple of other approaches that the opponent of human embryonic stem cell research can take in trying to articulate her objection to the practice, and I will try to explain these now.

I will first discuss what I will call the full moral standing approach. The idea is that we ought not to use stem cells in biomedical research because the human embryos from which they come have full moral standing already. This can be contrasted with the approach we were just considering, which does not take a position on the moral standing of human embryos but merely asserts that human embryos are the entities out of which beings with moral standing develop. To say that some thing has full moral standing is a shorthand way of saying that the thing is worthy of moral consideration in itself, in the way that a person is, and in addition that it is not worthy merely in relation to some other thing that has moral standing. For example, if it were true that some ancient oak tree 
had full moral standing, then it would be the case that it ought to be respected in certain ways for its own sake. Nobody ought to sacrifice it for the sake of botanical research, or even for the sake of building a hospital - not even if it was the last tree available and there were no other building materials. But, as this example suggests, simply saying that something has moral standing does not give it moral standing. (I am in no way suggesting, for my own part, that that any oak tree actually has moral standing equivalent to that of an adult human being. My point is just that to propose that idea as a reasonable one I would need to offer an explanation of why it is the kind of thing that is worthy of moral consideration in itself.)

If it were true that human embryos had full moral standing, then one thing that I would have to do to respect them would be to refrain from tearing off pieces of them to use for my own biomedical research, ever in order to save lives. We do not, after all, tear pieces off of living adult persons, or children, without their consent, to use in saving the lives of others. So it is important to ask: What is the basis of moral standing, such that we can decide whether a thing has it or not? Although this has been a subject of considerable debate, much of the debate has concerned issues that are not relevant to stem cells. For example, there has been a debate over whether what is required for moral standing is autonomy (self-governance), self-awareness ("self-consciousness," as philosophers call it), or mere sentience (consciousness) by itself. Many nonhuman animals, for example, are sentient but not self-aware or autonomous, and the debate over which of these things is the basis of moral standing carries implications for how we should treat these animals. ${ }^{8}$ But since a blastocyst is not autonomous, self-aware, or even sentient, the nuances of that debate are irrelevant here. For this reason let us focus only on those views that do assign human blastocysts moral standing. I will consider two of these: the species view and the divine-conferral view.

I will consider the species view only briefly because it has already been considered and criticized elsewhere. ${ }^{9}$ It holds that the basis of moral standing is membership in the human species. According to the view, any human being, even a very undeveloped, comatose, or severely cognitively impaired human being, has moral standing in virtue of species membership. This view implies that embryos, who are also members of the human species, have moral standing. Hence they are worthy of respect in the way that other humans who cannot represent their own interests are worthy of respect. In particular, because embryos cannot speak for themselves and cannot protect their own well-being, people must protect their well-being for them and must take them into account, just as they would take any other human being into account. ${ }^{10}$

The species view is usually criticized on the grounds that it is arbitrary. The assertion that a being has moral standing in virtue of its membership in the human species stands in need of further justification; by itself it does not render the idea of moral standing intelligible. Differences in species do not carry any obvious moral significance in themselves. This is brought out by the fact that it is perfectly imaginable that there might exist members of another species, very much like us in respect of their intelligence, way of life, and even appearance-yet these creatures would not be deemed worthy of full moral consideration by the species view because they were not members of the human species. The accidental fact that we know of no such creatures does not constitute a response to the objection because the species view implies that such creatures would not be worthy of moral consideration if they existed, and this seems plainly false. Since the view carries a false implication, it must be mistaken.

In addition, the species view is overinclusive. It is overinclusive because it implies that both sperm and egg, which are (haploid) members of the human species, have moral standing equivalent to that of adult humans. This seems counterintuitive. Although it would be possible to confine moral standing to diploid members of the human species, there is no justification for doing so that is not arbitrary or ad hoc. ${ }^{11}$

Other possible reasons might be offered to support the species view. For example, it is sometimes said that providing a guarantee of moral standing to every (diploid) member of the human species, including embryos, is conducive to mutual respect among all persons. In particular, treating embryos with respect enhances our ability to accord people dignity throughout their lives. This might be offered as a justification for treating every member of the human species, including human embryos, as having full moral standing. But what is striking about this kind of argument is that it does not support the conclusion that every member of the human species has moral standing. It merely supports the conclusion that every member of the human species ought to be accorded moral standing - whether or not it actually has that standing — because doing so helps to achieve better human relations all around. This is not just a quibble over wording. If a person has no other reason to regard a thing as having moral standing, besides this argument, then it will seem to her that she is being asked to participate in an elaborate pretense of respect toward an object that does not merit respect in its own right. It is especially difficult to defend this pretense when it carries high costs, such as 
preventing the acquisition of interesting and valuable knowledge, or preventing research that could save the lives of sick people. And in fact, since the argument depends on an unsubstantiated claim about what will lead to better human relations, it is not easy to defend.

Let us now turn to the divine-conferral view of moral standing, which holds that the reason why human embryos have moral standing is that God has conferred moral standing upon them. For example, in some Christian traditions, there is a belief that moral personhood begins at conception and that the human embryo is a member of the moral community. ${ }^{12}$ This view is thought to be supported by Scripture and tradition. However, rather than considering the details of any particular version of the view, here I will consider what is common to its many versions.

To understand and evaluate the divine-conferral view of moral standing, it is necessary to explain what kinds of things can be said to support it. I think that religious and nonreligious persons alike would agree that the grounds for believing that God has conferred moral standing on some being come only from the following sources: from religious experience (e.g., a revelation of some kind, or the answer to a prayer) or from some text or religious authority (e.g., the Bible or a religious leader).

The important thing to note is that it does not make sense to expect that other reasonable persons will equally appreciate either religiousexperiential or authority-based sources of belief. Different people have different religious experiences or no religious experiences at all; they adhere to different religious authorities or to no religious authorities at all. They are not unreasonable merely because they do not have the particular religious experience that is taken to support the claim that human embryos have moral standing or because they do not accept some particular religious authority on the matter as genuinely authoritative. Therefore, the divine-conferral view does not provide an adequate justification to these other people for the claim that we should not use human embryonic stem cells for research. ${ }^{13}$

Is there anything, then, that the opponent of human embryonic stem cell research can say to support the claim that human embryos have the same moral standing as adult human persons, something that ought to convince others who are initially unconvinced? I think that the answer to this question is "no." There is nothing, other than a religious or metaphysical conviction, to support this view. And one's own religious and metaphysical convictions, whatever merit one sees in them for oneself, have no rational force unless they are backed by reasonable arguments.
Moreover, simply saying that something has moral standing does not give it moral standing. I can say that the oak tree has moral standing, but that does not thereby make it the case that it does have moral standing. Suppose a hospital is really needed and the oak tree is the only source of lumber. Must it simply be accepted that the oak tree has moral standing and cannot be destroyed in order to build the hospital? Of course not. Because without a hospital there will be lives lost, it is terribly important to have something to say that will convince people affected by the decision that the oak tree is worthy of moral respect. Without this, one will have failed to justify why the tree cannot be destroyed for this purpose.

An alternative to the full moral standing approach is to hold that human embryonic stem cells have moral standing of a different sort from that of actual infants, children, and adult human persons. The most promising way of explaining this is to argue that the value of human embryos left over from IVF procedures is similar to the value of human body parts or recently deceased persons. We should think of human embryos, like human body parts or recently deceased persons, as having a special moral standing in virtue of their symbolic connection to a human life. This moral standing is not as strong as that attached to complete actual persons. However, it does imply obligations of care and responsibility that do not attach to ordinary property.

The best advocate of this view is Bonnie Steinbock. As a way of trying to articulate the idea of moral standing in question, Steinbock compares the standing of human embryos with the moral standing of recently deceased persons. She quotes Joel Feinberg:

As Feinberg explains: "It would be wrong, for example, to hack up Grandfather's body after he has died a natural death, and dispose of his remains in the trash can on a cold winter's morning. That would be wrong not because it violates Grandfather's rights; he is dead and no longer has the same sort of rights as the rest of us, and we can make it part of the example that he was not offended while alive at the thought of such posthumous treatment and indeed even consented to it in advance. Somehow acts of this kind if not forbidden would strike at our respect for living human persons (without which organized society would be impossible) in the most keenly threatening way." 14

Steinbock comments approvingly, "Just as disrespect for dead bodies can strike at our respect for living persons, so, too, I want to suggest, can inappropriate treatment or use of embryos. Embryos, as much as dead bodies, are a "potent symbol of human life," and for that reason have moral value and deserve respect, even though they lack interests, rights, 
and (therefore) moral [standing]." 15 Now, what is pertinent about this alternative approach to the moral value of human embryos is that we can accept it and still go on to say that human embryonic stem cell research is morally permissible. This is because of the implications of the analogy. It is entirely consistent with our idea of respect for the dead, or respect for body parts, that we may permissibly use dead bodies in research, or use body parts for research, or for organ and tissue transplantation. Likewise, it can be a way of treating a frozen human embryo with respect to employ it to help those who are alive. In fact, this act of using the embryo to save lives can have a very positive symbolic significance. Rather than letting an embryo go to waste in permanent frozen storage, or allowing an embryo that would have had no future as a human being anyway to die uselessly, it can instead come to have a new life and significance as a highly valued material that will help others to live.

Thus it does not follow from this alternative approach that human embryonic stem cell research is morally impermissible. On the contrary, this alternative approach affords us a way of investing human embryonic stem cell research with a kind of ritual significance as a way of respecting human life. Because the symbolism is plausible, it is reasonable to hold that the symbolic value of stem cell research is positive.

Still, I do not expect that resolute opponents of human embryonic stem cell research will accept the view on which using human embryos for research is a way of respecting them. They will reject the symbolism I have described and adhere instead to the view that such research involves killing human beings, or at a minimum involves something like the misuse of body parts. They will not be persuaded by the counterarguments I have given here. They will remain morally opposed to this research.

However, there is one final strategy that the opponents of stem cell research can use to try to show that we should not conduct human embryonic stem cell research. This strategy is based, not on the fact of the intrinsic immorality of human embryonic stem cell research-which has proven to be an argumentative dead end, or at least a stalemate of symbolism-but instead on the very fact that many people are offended by, or even disgusted by, such research. ${ }^{16}$ Although others may not be rationally obligated to accept the reasons these offended people have for feeling the way they do, this does not change their feelings, and we should at a minimum accept the principle that, other things equal, we should try to avoid causing people to feel offense or disgust. In this way, the opponents of human embryonic stem cell research can appeal to their own feelings of offense as a reason for others not to conduct such research.

This line of thinking may be enhanced where government money is concerned. For if the government financially supports human embryonic stem cell research, it is, in effect, acting on behalf of all the citizens from whom it draws taxes. I think it makes sense that it compounds the offense or disgust of the person opposed to human embryonic stem cell research to know that, not only is human embryonic stem cell research going on, but furthermore it is being supported by the government in that person's name.

The problem, of course, is that there is a trade-off between the resentment that would be felt by those on either side of the issue if the matter were not decided in their favor. Many patients with currently incurable diseases and their advocates would resent restrictions on human embryonic stem cell research and its funding; those who maintain that such research is morally impermissible would resent the legal permissibility of such research and the effort to give it public funding. Both parties belong to the same political society, so the conflict cannot be avoided. If the issue is not to be decided through rational argument, then the problem is how to resolve the issue in some other way that the parties to the conflict can accept.

It is at this point-where straightforward moral reasoning is discontinued, and we begin to take people's moral disagreement as a giventhat the issue becomes a distinctively political issue. To get past a fundamental moral disagreement, the two parties to the disagreement can adopt one of the following options within the political sphere. First, they can try to appeal to some common standard of reasoning that transcends their moral disagreement, perhaps by appealing only to beliefs and principles that they both share. Second, they can agree to disagree but accept a common procedure such as voting or judicial proceedings that they believe will resolve the issue fairly and in a way that they agree to accept, whatever the outcome, for the time being. Or third, they can fail to agree upon a common procedure for deciding the issue but continue to pursue the available means toward the outcome they desire. ${ }^{17}$

The issue of funding human embryonic stem cell research has been and will continue to be addressed in the second or third of these ways. If my argument in the first part of this essay is correct, there is little hope of deciding it in the first way-that is, by finding a shared set of moral premises for considering this issue and coming to a consensus, at least not in the near future. Despite this, I propose that the second way is 
better than the third; that is, it would be better if people could, by and large, at least agree on the legitimacy of a procedure for deciding whether to permit and to fund human embryonic stem cell research. But are there any prospects for finding such a consensual decision procedure?

Many things might count as consensual decision procedures. For example, we could decide to roll a die every ten years to determine whether human embryonic stem cell research would be funded by the National Institutes of Health for the following decade. We could decide to hold a national referendum on the issue. We could elect representatives and give them the power to decide. In my view, any of these procedures, if consented to by the vast majority of the people who have a stake in the matter, would be acceptable. (Yet I doubt that the roll of a die would, in fact, be acceptable to most people.)

However, at least one relevant alternative has certain limitations as consensual decision procedure: presidential executive order. A president is elected not merely to make a decision on a single issue but for a whole range of reasons. Although this is also true of the members of a legislature, a legislature has a formal, public procedure by which it decides individual questions. There is no counterpart in the case of an executive order. ${ }^{18}$ This is in no way to raise a general objection to executive orders. In matters where urgent action is needed, or where some plausible and effective interpretation of the law is an administrative necessity, an executive order is perfectly acceptable. But where the executive order involves highly controversial moral issues, it is best to supplement it with legislative action.

The current rule on the permissibility and funding of human embryonic stem cell research in the United States has been determined in part by presidential executive order and in part by a congressional attachment to the yearly Department of Health and Human Services appropriations bill. The executive order is President George W. Bush's order of August 9, 2001 , barring federal funding for research involving human embryonic stem cell lines created after that date. ${ }^{19}$ The congressional amendment, called the Dickey Amendment, has been renewed by Congress each year since it was initially passed in 1996 and is meant to prohibit federal funding for scientific work that creates or destroys human embryos for research purposes. Thus the applicable federal law is a mixture of executive order and congressional act. The executive order is most charitably construed as an interpretation of the Dickey Amendment, applying it to the issue of human embryonic stem cell research. ${ }^{20}$ The idea is that, if we confine federally funded research to existing stem cell lines, then the federal government will not be encouraging the creation or destruction of human embryos for research purposes. If the executive order is a legitimate interpretation of the Dickey Amendment, then it inherits the procedural legitimacy of that amendment.

However, the executive order is not the only reasonable interpretation of the Dickey Amendment. An alternative approach holds that it is possible, consistent with the Dickey Amendment, to allow federal funding of research using stem cell lines obtained from private, nongovernmentally funded sources. These would be derived, as discussed earlier, from embryos that are not on their way toward having future lives, such as those frozen in perpetuity after IVF treatments. The destruction of these embryos for research would then take place outside the domain of federal funding and would not involve the destruction of embryos that would have ever had future lives anyway. The research itself would take place within the federally funded domain.

Since there is more than one reasonable interpretation of the Dickey Amendment, and since the consequences of the interpretation are very significant, it is important to try to adjudicate the question through a procedure that all can agree on. However, it is not obvious that those whose views lie on different sides of this question would mostly agree in advance to the available procedures for deciding it, or perhaps even to the procedure of an open congressional debate leading to legislation. In that case, we would have already reached the third way of reaching a decision about human embryonic stem cells, where no procedure for deciding the question can be agreed upon by those who have a stake in the matter.

It is a notoriously difficult problem in political philosophy to determine what counts as agreement to a political or judicial decision procedure. Explicit acts by which a person binds himself to such a procedure are rare; on the other hand, exile and acts of genuine civil disobedience that express a definite lack of consent are also rare. A more common habitat for those who lose a struggle over political procedures is the middle zone of grudging obedience and continuing opposition. The ambiguity of this middle zone is compounded by difficulty in discerning whether people disagree with the decision procedure itself or merely with the outcome of the procedure. Because of these ambiguities, it is both important and difficult for opponents to show good faith toward one another throughout the process and even during the grudging aftermath. If possible, the procedure should be forged in a way that allows good faith to persist. That is my philosopher's second-ditch plea in this matter: if reason does not bring us to consensus over the issue of federal funding 
and legal regulation of human embryonic stem cell research, we might at least find a way for all parties to remain committed to the best possible shared political process as science and public opinion evolve.

\section{NOTES}

Thanks to Ron Miller and Lee Zwanziger, and to the attendees at the University of California, Irvine Conference on the Science, Ethics, and Politics of Stem Cells of May 22, 2004, for helpful comments on this paper.

I. Don Marquis advances this sort of argument as a criticism of abortion. See Marquis, "Why Abortion Is Immoral," Journal of Philosophy 86 (I989): I 83-202.

2. As Arthur Grant has helpfully pointed out to me, the benefits of human embryonic stem cell research are not merely medical and therapeutic but also intellectual. Because of the foundational role of embryonic stem cells in human development, they are inherently fascinating from a biological point of view.

3. See Philippa Foot, "Killing and Letting Die," in Abortion: Moral and Legal Perspectives, ed. J. Garfield and P. Hennessey (Amherst: University of Massachusetts Press, 1984), 177-85.

4. For a detailed discussion of related issues, see F. M. Kamm, Creation and Abortion: A Study in Moral and Legal Philosophy (New York: Oxford University Press, I992), and Morality, Mortality, vol. 2, Rights, Duties, and Status (New York: Oxford University Press, I996).

5. On the issue of whether it is worse to create an embryo with the intention of destroying it than to create it for some other purpose while foreseeing that it will be destroyed, see William Fitzpatrick, "Surplus Embryos, Nonreproductive Cloning, and the Intend/Foresee Distinction," Hastings Center Report 33 (May-June 2003): 29-36.

6. Woo Suk Hwang et al., "Evidence of a Pluripotent Human Embryonic Stem Cell Line Derived from a Cloned Blastocyst," Science 303 (March I2, 2004): $1669-74$.

7. Some critics raise a serious worry about the sale of embryos and egg cells on the grounds that there is undue pressure on women-financial or otherwiseto create embryos and egg cells for research and that this will contribute to an overall pattern of unfair treatment and exploitation of women. For example, it is claimed that in some of the South Korean research on somatic cell nuclear transfer, eggs were obtained from women researchers working under the lead scientist on the very study that was eventually published. It seems plausible to suggest that this practice places an unfair burden on women scientists; men obviously cannot be burdened in this way, and donating eggs requires an arduous procedure. This, I think, is a genuine reason to acquire such materials only through voluntary donation by third parties.

8. See, for example, Tom Regan, The Case for Animal Rights (Berkeley: University of California Press, I983).

9. The most well-known criticism is in Peter Singer, Animal Liberation (New York: New York Review of Books, I975). For a reply, see Carl Cohen, "The Case for the Use of Animals in Biomedical Research," New England Journal of
Medicine 3I5 (October 2, I986): 865-70. See also Mary Anne Warren, Moral Status: Obligations to Persons and Other Living Things (New York: Oxford University Press, 2000)

ro. See Robert P. George, “Stem-Cell Research: Don't Destroy Human Life," reprinted in The Future Is Now: America Confronts the New Genetics (New York: Rowman and Littlefield, 2002), 289-91.

II. Cf. George, "Stem-Cell Research": "Plainly gametes (sperm cells and ova) are not human beings. They are parts of other human beings. They lack the epigenetic primordia for internally directed growth and maturation as a distinct, complete, self-integrating human organism" (290). The expression epigenetic primordia suggests the theory of epigenesis, developed by Kaspar Friedrich Wolff in the eighteenth century, which holds (correctly) that the theory of "preformation"- - the view that one of the gametes contains a tiny version or predecessor of the developing organism out of which it develops-is false and that an organism instead develops through successive differentiations of the embryo. George's point is that because neither sperm nor egg reproduces, or grows by itself into some further organism like us, neither is a human being. Two of George's main points seem questionable. First, it seems odd to say that sperm cells and eggs are parts of the people in which they reside, just as organs are. Second, it does not follow from the claim that sperm and eggs do not reproduce or grow into some further organism on their own that they are not a kind of human being in the species sense.

r2. See Gilbert Meilaender, "Some Protestant Reflections," in The Human Embryonic Stem Cell Debate: Science, Ethics, and Public Policy, ed. Suzanne Holland et al. (Cambridge, MA: MIT Press, 200I), I4I-47.

I3. For a sensitive discussion of this general issue, see Kent Greenawalt, $R e-$ ligious Convictions and Political Choice (New York: Oxford University Press, I988).

I4. Bonnie Steinbock, "Respect for Human Embryos," in Cloning and the Future of Human Embryo Research, ed. Paul Lauritzen (New York: Oxford University Press, 200I), 2I-33, quoting Joel Feinberg, Freedom and Fulfillment (Princeton: Princeton University Press, I992), 53.

I 5. Steinbock, "Respect for Human Embryos," 29, quoting John Robertson, Children of Choice (Princeton: Princeton University Press, 1994), 37.

r6. See Leon R. Kass, "The Wisdom of Repugnance," in Leon R. Kass and James Q. Wilson, The Ethics of Human Cloning (Washington, DC: American Enterprise Institute, I998), 3-59, esp. I 8-19.

I7. On these issues, see Thomas Nagel, "Moral Conflict and Political Legitimacy," Philosophy and Public Affairs .I6 (1987): 21 5-40; John Rawls, Political Liberalism (New York: Columbia University Press, I993), and A Theory of Justice (Cambridge, MA: Harvard University Press, I97I); and Gerald Gaus, Justificatory Liberalism (New York: Oxford University Press, I996). I thank Aaron James for discussion of this point.

r8. A judicial solution shows similar drawbacks. In the case of many controversial issues, constitutional rights are often at stake, so there is a legitimate role for the courts. But this does not mean that the courts are the best place to decide morally significant political questions. 
19. The president recently (in 2006) vetoed a bill that would have overturned his executive order, and Congress was unable to override this veto.

20. For discussion of this point, see President's Council on Bioethics, Monitoring Stem Cell Research, January 2004, ch. 2, available at www.bioethics.gov/ reports/stemcell/; and George Q. Daley, "Missed Opportunities in Embryonic Stem-Cell Research," New England Journal of Medicine 35I (August I 2, 2004): $627-28$.

\title{
Religious Perspectives on Embryonic Stem Cell Research
}

\author{
Mahtab Jafari, Fanny Elabi, Saba Ozyurt, \\ and Ted Wrigley
}

Human embryonic stem cells derive from the inner cell mass within an early-stage embryo called a blastocyst, which forms five to six days after conception and approximates a hollow ball of roughly one hundred cells. As development continues, cells of the inner cell mass grow and differentiate, ultimately assuming the specialized characteristics of the major organ systems. Many scientists believe that these pluripotential embryonic stem cells have the potential to improve the knowledge and treatment of life-threatening diseases such as cancer, Alzheimer's disease, diabetes, spinal cord injury, multiple sclerosis, cancer, and heart diseases. However, the use of these cells for medical research presents an ethical double-edged sword in that the potential value to human life is countered by philosophical questions about the destruction of human life. Any proposed solution to this controversy is sure to conflict with the strongly held moral and religious convictions of one group or another. What has been missing in this dialogue is a dispassionate exposition covering the range of religious views on this important topic; this chapter fills that void.

The fundamental issue of the beginning of human life appears to have created an unwarranted tension between science and religion when it comes to embryonic stem cell research. Is this one-hundred-cell blastocyst a human person? Does it have a soul? Our belief systems, regardless of our educational background, influence our views with regard to embryonic stem cell research. As we consider this critical issue, it is important 